\title{
Distribution of Viruses Infecting Cucurbit Crops and Isolation of Potential New Virus-Like Sequences from Weeds in Oklahoma
}

\author{
Akhtar Ali, Osama Mohammad, and Abeer Khattab, Department of Biological Science, The University of Tulsa, Tulsa, OK 74104
}

\begin{abstract}
Ali, A., Mohammad, O., and Khattab, A. 2012. Distribution of viruses infecting cucurbit crops and isolation of potential new virus-like sequences from weeds in Oklahoma. Plant Dis. 96:243-248.

Field surveys were conducted from 2008 to 2010 to detect and determine the incidence of viruses in the major cucurbit-growing areas of Oklahoma. In total, 1,049 symptomatic leaf samples (890 from cucurbits, 109 from weed species, and 50 from crop plants [agricultural crops]) were collected from 90 fields in four counties (Atoka, Blaine, Jefferson, and Tulsa) of Oklahoma. Samples were tested against seven viruses, including Cucumber mosaic virus (CMV), Cucumber green mottle mosaic virus (CGMMV), Melon necrotic spot virus (MNSV), Papaya ringspot virus-watermelon strain (PRSV-W, formerly known as Watermelon mosaic virus-1), Squash mosaic virus (SqMV), Watermelon mosaic virus-2 (WMV-2), and Zucchini yellow mosaic virus (ZYMV), using dot-immunobinding assay (DIBA). Results showed the

highest incidence for PRSV (51\%), followed by WMV-2 (14\%) and ZYMV (10\%) among the collected samples. SqMV, MNSV, and CMV were detected in $3.8,3.3$, and $1.1 \%$ of the samples, respectively. None of the samples collected during surveys reacted positively against the antiserum of CGMMV. Mixed virus infections were common involving two $(5.18 \%)$ or three $(4.61 \%)$ viruses in various combinations. New weed host species were found to be infected with PRSV when confirmed by both DIBA and reverse-transcription polymerase chain reaction (RT-PCR). Some weed species contained possible new viruses when analyzed by random RT-PCR, followed by cloning, sequencing, and BLAST analysis with sequences in GenBank.
\end{abstract}

Cucurbits (cucumber, cantaloupe, pumpkin, watermelon, and zucchini squash) are economically important cash crops worldwide, including the United States. Virus diseases are a major constraint in commercial cucurbit production $(21,27)$, causing sporadic epidemics. More than 39 different viruses have been reported to cause cucurbit diseases and many are responsible for economic losses in the quality and quantity of cucurbit crops $(15,18,27)$.

In the United States, cucurbit crops are grown in several states and are commonly infected by a number of viruses. Several of these viruses, particularly the Potyvirus spp. Papaya ringspot virus-watermelon strain (PRSV-W, formerly known as Watermelon mosaic virus-1) (29), Watermelon mosaic virus-2 (WMV-2) (30), Zucchini yellow mosaic virus (ZYMV) $(19,20)$, and Cucumber mosaic virus (CMV) (9), are the most frequently encountered and economically important $(24,27)$. These viruses have been shown to infect cucurbit crops in major cucurbit-growing areas of California and Connecticut $(25,28)$, Florida $(1,31)$, Hawaii (35), Illinois (14), New Jersey (7), New York $(25,28)$, South Carolina (34), and Texas $(5,11,12,22)$. These viruses are transmitted by many aphid species in a nonpersistent manner. This makes them difficult to control by insecticidal sprays because the aphids are capable of rapidly transmitting the viruses before the insecticides can kill them (36). These viruses are a significant and continuous threat to cucurbit production in these regions.

In Oklahoma, cucurbit crops, including cucumber, melon, squash, pumpkin, and watermelon, are grown on about 5,088 acres annually (26). Among these, watermelon is a very important cash crop (grown on approximately 4,500 acres) and currently generates $\$ 3.5$ million annually in farm income. Several virus-like mosaic diseases have been observed in Oklahoma for the last several years that affect cucurbit crops, particularly watermelon and pumpkin. Natural incidence of PRSV-W, WMV-2, ZYMV, CMV, and Squash

Corresponding author: A. Ali, E-mail: Akhtar-ali@utulsa.edu

Accepted for publication 6 September 2011.

http://dx.doi.org/10.1094/PDIS-05-11-0419

(C) 2012 The American Phytopathological Society mosaic virus (SqMV) with pumpkin has been reported in field trials located at the Vegetable Research Station Bixby and Wes Watkins Agricultural Research and Education Center in Lane, OK (6). However, there is no detailed information on the incidence, ecology, spread, and distribution of these viruses in watermelon and other cucurbit crops in the commercial grower's fields. Information on the identity and distribution of viruses and potential reservoir hosts in major cucurbit production areas is important in developing and implementing effective control strategies for virus diseases in local areas. In addition, accurate virus identification and detailed information about prevalent viruses in a particular region is important for growers.

The purpose of this study was to determine the incidence and distribution of the most prevalent viruses infecting cucurbit crops in the grower fields, and identify their potential reservoir hosts in the major growing areas of Oklahoma.

\section{Materials and Methods}

Seed, antisera, and positive control of viruses. Squash seed was kindly provided by Marilyn Roossinck, the Samuel Roberts Noble Foundation, Ardmore, OK. Seven kits that included polyclonal antiserum and positive controls of CMV, Cucumber green mottle mosaic virus (CGMMV), Melon necrotic spot virus (MNSV), PRSV-W, SqMV, WMV-2, and ZYMV were obtained commercially (AC Diagnostics, Arkansas, and Agdia, Inc., Indiana). Positive controls of all seven viruses were supplied in lyophilized form with the kits and were resuspended in the sampled buffer as recommended by the manufacturers' instructions (AC Diagnostics and Agdia, Inc.).

Survey area and sample collections. Surveys of cucurbit crops (cantaloupe, cucumber, pumpkin, squash, and watermelon) and weeds within adjacent fields were conducted during the growing seasons of 2008, 2009, and 2010 in four counties of Oklahoma that included Atoka, Blaine, Jefferson, and Tulsa (Fig. 1). Atoka County is located in the south, Blain County in the west, Jefferson County in the southwest, and Tulsa County in the east of Oklahoma.

Surveys were conducted from July to August of the growing seasons and only symptomatic samples were collected randomly throughout the field in each county. Selected fields were at a dis- 
tance of 2 to 3 miles from each other and were sampled once during the growing season. The size of the field varied from 1 to 50 acres. Numbers of samples (5 to 30 samples/field) were collected according to the size of the field.

In total, 1,049 samples were collected from 90 fields that included 219 samples from 24 fields in Atoka County, 338 samples from 23 fields in Blaine County, 64 samples from 7 fields in Jefferson County, and 428 samples from 36 fields in Tulsa County. About two to three leaves per sample were collected from the shoot apex of symptomatic plants and were labeled and placed in separate plastic bags. Samples were transported to the laboratory on ice and kept at $4^{\circ} \mathrm{C}$. All samples were processed within $24 \mathrm{~h}$ of collection.

Sample preparation and dot-immunobinding assay. All samples were prepared and tested by dot-immunobinding (DIBA) as described previously (3), with minor modifications. Sap from individual leaves was extracted by crushing approximately $100 \mathrm{mg}$ of leaf tissue in individual plastic bags containing 1 volume of phosphate-buffered saline (PBS) buffer (137 mM NaCl, $3 \mathrm{mM} \mathrm{KCL}, 8$ $\mathrm{mM} \mathrm{Na}_{2} \mathrm{HPO}_{4}$, and $1 \mathrm{mM} \mathrm{KH} \mathrm{PO}_{4}, \mathrm{pH}$ 7.4). Extracted sap was centrifuged for $2 \mathrm{~min}$ and $2 \mu \mathrm{l}$ of supernatant was dotted on the nitrocellulose membrane. Each sample was dotted seven times on seven different nitrocellulose membranes. Each membrane was dotted with negative and positive controls. Sap from uninoculated watermelon or squash seedlings grown in the growth chambers was used as a negative control. A positive control for each virus was obtained commercially (AC Diagnostics and Agdia, Inc.). Membranes were air dried and processed immediately or stored at $4{ }^{\circ} \mathrm{C}$ for later processing. Membrane-blocking solution was prepared by homogenizing healthy cotyledons of squash in 9 volumes (wt/vol) of PBS buffer. Glucose $(600 \mathrm{mM})$ and mannose $(600 \mathrm{mM})$ were added to the membrane-blocking solution. All samples were tested against antisera of CMV, CGMMV, MNSV, PRSV-W, SqMV, WMV-2, and ZYMV.

Reverse-transcription polymerase chain reaction. To further confirm the infection of PRSV-W and WMV-2 in weed species and mixed infections of cucurbit positive samples by DIBA, total RNA was extracted from leaves according to the Tri-Reagent procedure (Molecular Research Center Inc.) and was used in reverse-transcription polymerase chain reaction (RT-PCR) using the Superscript III Reverse Transcription Kit (Invitrogen) according to the manufacturer's instructions. Primers for the coat protein genes of PRSV-W (forward-5'-GCAGCAATGATAGAGTCATG-3' and reverse 5'-AACACACAAGCGCGAGTATTCA-3') and WMV-2 (forward 5'-AACACACAACCAAGT GAATT-3' and reverse 5'TAACGACCCGAAATGCTAACT- $3^{\prime}$ ) were designed from the published sequences in the National Center for Biotechnology Information database. PCR amplification was carried out using virus-specific forward and reverse primers with a total volume of $20 \mu \mathrm{l}$ in the presence of Taq DNA polymerase (Roche Applied Science) with 30 to 35 cycles of the following profile: $94^{\circ} \mathrm{C}$ for 2 min, $94^{\circ} \mathrm{C}$ for $30 \mathrm{~s}$, annealing at the 48 to $50^{\circ} \mathrm{C}$, and elongation at $72^{\circ} \mathrm{C}$ for $40 \mathrm{~s}$, with a final extension step at $72^{\circ} \mathrm{C}$ for $10 \mathrm{~min}$.

Pathogenicity tests. To confirm the pathogenicity of the detected viruses, some of the DIBA-positive samples with CMV,

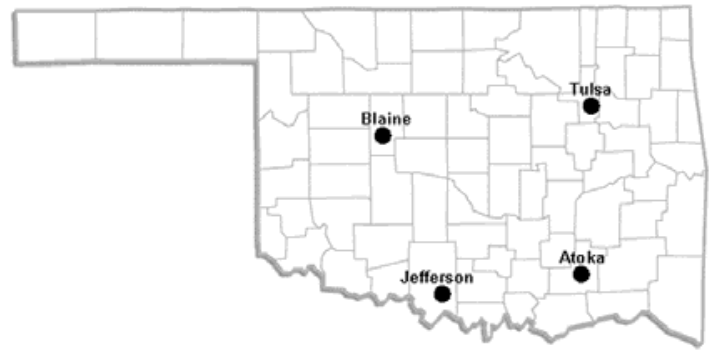

Fig. 1. Map of Oklahoma showing locations of four different counties where 1,049 samples were collected from cucurbit crops as well as weeds and other hosts and were tested by dot-immunobinding assay against seven different viruses.
PRSV-W, SqMV, WMV-2, and ZYMV collected during 2009 and 2010 were mechanically inoculated to squash ('Elite') seedlings using $0.1 \mathrm{M} \mathrm{K}_{2} \mathrm{HPO}_{4}$ buffer and kept in growth chambers for symptom development. Three to four weeks post inoculation, all inoculated seedlings were tested again by DIBA and some by RTPCR using PRSV-W and WMV-2 coat-protein-specific primers as mentioned above.

Preparation of virus-like particles, isolation of nucleic acids, and amplification. During the 2010 growing season, a few host species, showing unique symptoms (yellowing, leaf rolling, upward cupping, mottling, and stunting) and negative by DIBA to the above viruses, were selected for virus-like particle (VLP) preparations. Symptomatic leaves of Solanum carolinense L. (horse nettle) from Blaine County, Cucurbita foetidissima Kunth (wild gourd) from Jefferson County, and Palmer's Amaranth and Xanthium strumarium L. (cocklebur) from Tulsa County were used for VLP preparations. Sections (1 $\mathrm{g}$ each) of young leaves were ground in extraction buffer $(0.4 \mathrm{M}$ sodium citrate, $\mathrm{pH} 6.5)$ containing $0.5 \mathrm{M}$ iodoacetamide and $0.5 \mathrm{M}$ sodium diethyldithiocarbamic acid trihydrate. The homogenate was filtered through cheesecloth. Following differential centrifugation, the supernatant was centrifuged on a sucrose cushion at $35,000 \mathrm{rpm}$ for $45 \mathrm{~min}$ to pellet virus particles. The pellet was resuspended in sterile water. Nucleic acids were isolated as described previously (23) and amplified by RT-PCR using random hexamer primer as described by Roossinck et al. (32).

Cloning, sequencing, and sequence analysis. Amplified random hexamers RT-PCR products were purified using the QIAquick PCR kit (Qiagen) and eluted in $50 \mu \mathrm{l}$ of water. Eluted PCR product (3 $\mu \mathrm{l})$ was ligated using the pGEM-T Easy Vector System (Promega Corp.) according to the manufacturer's instructions and transformed into Escherichia coli DH5 $\alpha$ competent cells (New England BioLabs) (33). Positive recombinant white colonies were selected on the Luria-Bertani agar plates containing appropriate antibiotics, isopropyl-thio-galactopyranoside, and X-gal (33). Plasmid DNA preparations were obtained using QIAprep spin Miniprep Kit (Qiagen). At least three to five clones were selected from each cDNA library per sample for sequencing. Sequencing was performed using dye terminator cycle sequencing (Applied Biosystems 3130 Genetic Analyzer) at the core facility of the Department of Biological Science, The University of Tulsa, Oklahoma.

Sequences were analyzed using Basic Local Alignment Search Tool (BLAST) with both nucleotide versus nucleotide (BLASTn) and translated nucleotide versus protein (BLASTx) queries in GenBank databases for nucleotides and proteins using an $e$ value $(, 23)$. The top three to five hits against each database were reported for each sequence.

\section{Results}

Symptoms on cucurbit crops. The most commonly observed symptoms on all cucurbit crops ranged from mild to severe mosaic, mottling, stunting, leaf narrowing, shoestring appearance of the leaf, leaf rolling and upward cupping, vein clearing, yellowing and reduction of leaf and fruit size. Blistering, color breaking of fruit, ringspots, wilting of flower, and fruit deformations commonly were observed on pumpkin. Due to mixed infections, it was difficult to identify the symptoms of a particular virus in the field.

Occurrence and detection of viruses by DIBA. Six of the seven viruses were detected in samples collected from all four counties, while none of the samples were positive to CGMMV. CGMMV (genus Tobamovirus) is a severe virus of watermelon and other cucurbits in Asia and 15\% losses has been reported in cucumber. At least three viruses were detected from each Oklahoma county. Three viruses-PRSV-W, WMV-2, and ZYMV-were detected in all four counties.

PRSV-W was the most prevalent virus, being detected in 521 samples collected from different cucurbits in the four counties of Oklahoma. PRSV-W was found in all cucurbit crops.

Distribution of viruses in different counties and crops. In Atoka County, five viruses were detected but none of the samples were positive to CMV. Similarly, in Blaine County, five viruses 
were detected but none of the samples reacted to the antiserum of MNSV. In Jefferson County, only three Potyvirus spp. were found, mostly in watermelon and cantaloupe, but none of the remaining viruses. In Tulsa County, all seven viruses except CGMMV were detected by DIBA. The average incidence of PRSV-W was higher in every county compared with the other viruses tested. Samples from every field were positive to at least one virus.

CMV was detected in only one pumpkin and three watermelon samples during the 3 years of the study, indicating a low incidence of CMV in cucurbits.

MNSV was detected in 35 cucurbit samples collected in 2008 in Atoka and Tulsa Counties, In Atoka County, MSNV was detected in all cucurbits except watermelon. In Tulsa County, MNSV was detected in all cucurbits except cucumber. None of the samples collected in the 2009 and 2010 growing seasons were positive for MNSV.

The infection rate of PRSV-W in watermelon was $60 \%$ in Atoka, $55.8 \%$ in Blaine, $60.8 \%$ in Jefferson, and $77 \%$ in Tulsa Counties (Table 1). The infection rate of PRSV-W in other cucurbits ranged from 0 to $74.6 \%$ in cantaloupe, 0 to $51 \%$ in pumpkin, 0 to $57 \%$ in cucumber, and 33 to $35 \%$ in squash.

PRSV-W was also detected in 19 samples obtained from various weed species (Table 2) in all counties except Blaine County. Double and triple infections of PRSV-W were recorded with most of the viruses identified in this study except CMV (Table 3).

SqMV was detected in 40 samples collected from all counties except Jefferson County (Table 4). Of the 40 samples, 37 samples were collected from four cucurbit crops (Table 1) and 3 from morning glory in Tulsa County (Table 2). Individual infections of SqMV were recorded only in 9 samples, while the remaining 31 positive samples of SqMV had mixed infections of two or three viruses (Table 3).

WMV-2 was detected in 146 samples and had the second highest incidence in this study (Table 4). WMV-2 was mostly found in watermelon and in few samples of other cucurbit crops (Table 1). Nine samples from pigweed were also positive for WMV-2 in Tulsa County (Table 2). WMV-2 was detected in three double infections and three triple infections with all other viruses detected in this study except MNSV (Table 3).
ZYMV was detected in 98 samples of watermelon, one sample from cantaloupe, one sample of wild gourd and 2 samples of morning glory (Tables 1 and 2). None of the samples collected from other cucurbit crops were positive for ZYMV (Table 1). ZYMV was detected in all four counties, with an average incidence of 0.93 to $12.7 \%$ (Table 4). ZYMV was detected in one double and two triple infections with PRSV-W, WMV-2, and SqMV (Table 3).

Mixed infection of viruses. Mixed infections were found in 164 samples (18.9\%). Two-thirds of the samples were doubly infected, one-third was triply infected, and no sample had more than 3 viruses. There were eight different combinations of mixed virus infections (Table 3). The highest incidence (approximately 5.2\%) was recorded for the double infection of PRSV-W and WMV-2, followed by triple infections of PRSV-W, WMV-2, and ZYMV $(4.6 \%)$, and WMV-2 and ZYMV (2.8\%). Mixed viral infections varied among the four counties (Table 3). Double infection of PRSV-W and WMV-2 was commonly found in all counties and was mostly observed in watermelon. Similarly, triple infection of PRSV-W, WMV-2, and ZYMV was also more commonly observed in watermelon. RT-PCR results confirmed the mixed infections of PRSV-W and WMV-2 in both cucurbits and weeds plants by amplifying the expected PCR products when analyzed by gel electrophoresis (data not shown).

Pathogenicity tests. All five viruses (CMV, PRSV-W, SqMV, WMV-2, and ZYMV) produced mosaic and mottling symptoms 1 to 2 weeks post inoculation and were also detected positive by DIBA and RT-PCR. Some of the PCR products from plants inoculated with PRSV-W and WMV-2 were also cloned and sequenced. Nucleotide sequence analysis confirmed the infection of PRSV-W and WMV-2 at the molecular level from the inoculated plants (data not shown).

Viruses in weeds and adjacent crops. To determine potential reservoir hosts for cucurbit viruses in Oklahoma, 109 weed and 50 crop plants samples were collected within cucurbit crops or crops adjacent to cucurbit fields (Table 2). Out of 109 samples, 34 samples from various weeds were positive for PRSV-W, SqMV, WMV2, and ZYMV by DIBA. Of the positive samples, PRSV-W was detected in 19 samples representing four different weed species (Amaranthus palmeri S. Wats, C. foetidissima Kunth, Physalis

Table 1. Incidence of viruses in individual cucurbit crops from symptomatic samples collected in four counties of Oklahoma during 2008 to 2010

\begin{tabular}{|c|c|c|c|c|c|c|c|c|}
\hline \multirow[b]{2}{*}{ County, crops } & \multirow[b]{2}{*}{ Samples collected } & \multicolumn{7}{|c|}{ Number of samples positive by DIBA ${ }^{a}$} \\
\hline & & CMV & CGGMV & MNSV & PRSV-W & SqMV & WMV-2 & ZYMV \\
\hline \multicolumn{9}{|l|}{$\overline{\text { Atoka }}$} \\
\hline Cantaloupe & 11 & 0 & 0 & 1 & 0 & 1 & 1 & 1 \\
\hline Cucumber & 14 & 0 & 0 & 4 & 8 & 0 & 0 & 0 \\
\hline Pumpkin & 49 & 0 & 0 & 4 & 21 & 3 & 0 & 0 \\
\hline Squash & 12 & 0 & 0 & 3 & 4 & 2 & 0 & 0 \\
\hline Watermelon & 108 & 0 & 0 & 0 & 65 & 2 & 34 & 27 \\
\hline Total & 194 & 0 & 0 & 12 & 98 & 8 & 35 & 28 \\
\hline \multicolumn{9}{|l|}{ Blaine } \\
\hline Cantaloupe & 2 & 0 & 0 & 0 & 0 & 0 & 0 & 0 \\
\hline Cucumber & 1 & 0 & 0 & 0 & 0 & 0 & 0 & 0 \\
\hline Pumpkin & 11 & 0 & 0 & 0 & 0 & 0 & 0 & 0 \\
\hline Watermelon & 310 & 3 & 0 & 0 & 173 & 25 & 63 & 67 \\
\hline Total & 324 & 3 & 0 & 0 & 173 & 25 & 63 & 67 \\
\hline \multicolumn{9}{|l|}{ Jefferson } \\
\hline Cantaloupe & 10 & 0 & 0 & 0 & 4 & 0 & 5 & 0 \\
\hline Watermelon & 46 & 0 & 0 & 0 & 28 & 0 & 18 & 1 \\
\hline Total & 56 & 0 & 0 & 0 & 32 & 0 & 23 & 1 \\
\hline \multicolumn{9}{|l|}{ Tulsa } \\
\hline Cantaloupe & 71 & 0 & 0 & 3 & 53 & 3 & 1 & 0 \\
\hline Cucumber & 2 & 0 & 0 & 0 & 0 & 0 & 0 & 0 \\
\hline Pumpkin & 41 & 1 & 0 & 6 & 21 & 0 & 2 & 0 \\
\hline Squash & 28 & 0 & 0 & 4 & 10 & 1 & 2 & 0 \\
\hline Watermelon & 174 & 3 & 0 & 10 & 134 & 0 & 11 & 2 \\
\hline Total & 316 & 4 & 0 & 23 & 218 & 4 & 16 & 2 \\
\hline Total & 890 & 7 & 0 & 35 & 521 & 37 & 137 & 98 \\
\hline
\end{tabular}

${ }^{\mathrm{a}} \mathrm{DIBA}=$ dot-immunobinding assay. Viruses: $\mathrm{CMV}=$ Cucumber mosaic virus, $\mathrm{CGMMV}=$ Cucumber green mottle mosaic virus, MNSV $=$ Melon necrotic spot virus, $\mathrm{PRSV}-\mathrm{W}=$ Papaya ringspot virus-watermelon strain, $\mathrm{SqMV}=$ Squash mosaic virus, WMV-2 = Watermelon mosaic virus-2, and ZYMV = Zucchini yellow mosaic virus. 
Table 2. Detection of viruses in weeds collected within or adjacent to cucurbit fields during 2008 to 2010

\begin{tabular}{|c|c|c|c|c|c|c|c|}
\hline \multirow[b]{2}{*}{ County, host species (scientific name) } & \multirow[b]{2}{*}{ Common name } & \multirow[b]{2}{*}{ Samples collected } & \multicolumn{5}{|c|}{ Number of samples positive by DIBA ${ }^{a}$} \\
\hline & & & CMV & PRSV-W & SqMV & WMV-2 & ZYMV \\
\hline \multicolumn{8}{|l|}{ Atoka } \\
\hline Amaranthus palmeri S. Wats & Palmer's Amaranth & 1 & 0 & 0 & 0 & 0 & 0 \\
\hline Ipomoea hederacea Jacq. & Morning glory & 2 & 0 & 0 & 0 & 0 & 0 \\
\hline Physalis angulata $\mathrm{L}$. & Ground cherry & 14 & 0 & 7 & 0 & 0 & 0 \\
\hline Solanum nigrum & Nightshade & 7 & 0 & 2 & 0 & 0 & 0 \\
\hline Total & $\ldots$ & 24 & 0 & 9 & 0 & 0 & 0 \\
\hline \multicolumn{8}{|l|}{ Blaine } \\
\hline A. palmeri S. Wats & Palmer's Amaranth & 2 & 0 & 0 & 0 & 0 & 0 \\
\hline Proboscidea louisianica & Devil's-claw & 2 & 0 & 0 & 0 & 0 & 0 \\
\hline S. carolinense $\mathrm{L}$. & Horse nettle & 9 & 0 & 0 & 0 & 0 & 0 \\
\hline S. rostratum Dunal & Buffalobur & 1 & 0 & 0 & 0 & 0 & 0 \\
\hline Total & $\ldots$ & 14 & 0 & 0 & 0 & 0 & 0 \\
\hline \multicolumn{8}{|l|}{ Jefferson } \\
\hline Ambrosia artemisifolia & Ragweed & 1 & 0 & 0 & 0 & 0 & 0 \\
\hline Cucurbita foetidissima Kunth & Wild gourd & 7 & 0 & 1 & 0 & 0 & 1 \\
\hline Total & $\ldots$ & 8 & 0 & 1 & 0 & 0 & 1 \\
\hline \multicolumn{8}{|l|}{ Tulsa } \\
\hline Amaranthus palmeri S. Wats & Palmer's Amaranth & 43 & 0 & 6 & 0 & 9 & 0 \\
\hline I. hederacea Jacq. & Morning glory & 9 & 0 & 0 & 3 & 0 & 2 \\
\hline Physalis angulata $\mathrm{L}$. & Ground cherry & 3 & 0 & 3 & 0 & 0 & 0 \\
\hline Xanthium strumarium L. & Cocklebur & 8 & 0 & 0 & 0 & 0 & 0 \\
\hline Total & $\ldots$ & 63 & 0 & 9 & 3 & 9 & 2 \\
\hline Total & $\ldots$ & 109 & 0 & 19 & 3 & 9 & 3 \\
\hline
\end{tabular}

${ }^{\mathrm{a}} \mathrm{DIBA}=$ dot-immunobinding assay. Viruses: CMV = Cucumber mosaic virus, PRSV-W = Papaya ringspot virus-watermelon strain, SqMV = Squash mosaic virus, WMV-2 = Watermelon mosaic virus-2, and ZYMV = Zucchini yellow mosaic virus.

Table 3. Number of samples with mixed infection of viruses in cucurbit crops during 2008 to 2010 as determined by dot-immunobinding assay ${ }^{\text {a }}$

\begin{tabular}{|c|c|c|c|c|c|c|c|c|c|}
\hline \multirow[b]{2}{*}{ County, crops } & \multirow[b]{2}{*}{ Mixed/total $^{\mathbf{b}}$} & \multicolumn{5}{|c|}{ Double infections } & \multicolumn{3}{|c|}{ Triple infections } \\
\hline & & $\begin{array}{l}\text { PRSV + } \\
\text { MNSV }\end{array}$ & $\begin{array}{l}\text { PRSV + } \\
\text { SqMV }\end{array}$ & $\begin{array}{l}\text { PRSV + } \\
\text { WMV-2 }\end{array}$ & $\begin{array}{l}\text { WMV-2+ } \\
\text { ZYMV }\end{array}$ & $\begin{array}{l}\text { SqMV + } \\
\text { WMV-2 }\end{array}$ & $\begin{array}{c}\text { PRSV + WMV-2 } \\
\text { + ZYMV }\end{array}$ & $\begin{array}{c}\text { PRSV + SqMV } \\
\text { + WMV-2 }\end{array}$ & $\begin{array}{l}\text { SqMV + WMV-2 } \\
+ \text { ZYMV }\end{array}$ \\
\hline \multicolumn{10}{|l|}{ Atoka } \\
\hline Cucumber & $2 / 14$ & 2 & 0 & 0 & 0 & 0 & 0 & 0 & 0 \\
\hline Pumpkin & $6 / 49$ & 3 & 3 & 0 & 0 & 0 & 0 & 0 & 0 \\
\hline Squash & $2 / 12$ & 0 & 2 & 0 & 0 & 0 & 0 & 0 & 0 \\
\hline Watermelon & $36 / 108$ & 1 & 0 & 7 & 21 & 0 & 7 & 0 & 0 \\
\hline Total & $46 / 183$ & 6 & 5 & 7 & 21 & 0 & 7 & 0 & 0 \\
\hline \multicolumn{10}{|l|}{ Blaine } \\
\hline Watermelon & $76 / 310$ & 0 & 13 & 19 & 4 & 5 & 33 & 2 & 0 \\
\hline Total & $76 / 310$ & 0 & 13 & 19 & 4 & 5 & 33 & 2 & 0 \\
\hline \multicolumn{10}{|l|}{ Jefferson } \\
\hline Watermelon & $7 / 46$ & 0 & 0 & 7 & 0 & 0 & 0 & 0 & 0 \\
\hline Wild gourd & $1 / 7$ & 0 & 0 & 1 & 0 & 0 & 0 & 0 & 0 \\
\hline Total & $8 / 53$ & 0 & 0 & 8 & 0 & 0 & 0 & 0 & 0 \\
\hline \multicolumn{10}{|l|}{ Tulsa } \\
\hline Cantaloupe & $4 / 71$ & 2 & 0 & 0 & 0 & 0 & 0 & 0 & 2 \\
\hline Pumpkin & $6 / 41$ & 5 & 0 & 1 & 0 & 0 & 0 & 0 & 0 \\
\hline Squash & $1 / 28$ & 0 & 0 & 0 & 0 & 0 & 0 & 0 & 1 \\
\hline Watermelon & $20 / 174$ & 10 & 0 & 10 & 0 & 0 & 0 & 0 & 0 \\
\hline Morning glory & $3 / 9$ & 0 & 0 & 0 & 0 & 3 & 0 & 0 & 0 \\
\hline Total & $34 / 323$ & 17 & 0 & 11 & 0 & 0 & 0 & 0 & 3 \\
\hline Total & $164 / 869$ & 23 & 18 & 45 & 25 & 8 & 40 & 2 & 3 \\
\hline Percent ${ }^{c}$ & 18.87 & 2.64 & 2.07 & 5.18 & 2.88 & 0.92 & 4.60 & 0.23 & 0.34 \\
\hline
\end{tabular}

${ }^{a}$ Viruses: PRSV = Papaya ringspot virus, $\mathrm{MNSV}=$ Melon necrotic spot virus, $\mathrm{SqMV}=$ Squash mosaic virus, WMV-2 = Watermelon mosaic virus-2, and ZYMV = Zucchini yellow mosaic virus.

b Number of mixed infections/total tested.

c Percentage of combined positive samples.

angulata $\mathrm{L}$, and $S$. nigrum) in three counties, SqMV in Ipomoea hederacea Jacq., WMV-2 in A. palmeri S. Wats, and ZYMV in $C$. foetidissima Kunth and I. hederacea Jacq. by DIBA. Three of the four weed species infected by PRSV-W belong to the Amaranthaceae and Solanaceae families, which are the new non-cucurbit host of PRSV (Table 2). Of the 50 crop plants samples (including alfalfa, okra, pepper, snap bean, soybean, and tomato), only 5 samples from pepper were positive to CMV.

Detection of unknown viruses. Results of random PCR amplification showed a faint smear or discrete bands on agarose gel (data not shown) in all six samples of four weed species tested.
Sequences from 24 clones representing six samples were obtained that varied in length from 371 to 940 nucleotides for various samples. BLASTn and BLASTx searches indicated that some sequences were of viral and plant origins while some samples had very little match to anything in the GenBank database. Two samples of $X$. strumarium L. (cocklebur) collected in Tulsa County (Table 2) contained a virus similar to Tobacco ringspot virus (TRSV). Similarly, a small portion of sequence from two clones of $S$. carolinense L. (horse nettle) samples collected in Blaine County (Table 2) matched with Cestrum yellow leaf curling virus and Dahlia mosaic virus, indicating potential viral origin. 
Table 4. Incidence of viruses in cucurbit crops from symptomatic samples collected in four counties of Oklahoma during 2008 to 2010

\begin{tabular}{|c|c|c|c|c|c|c|c|}
\hline \multirow[b]{2}{*}{ County } & \multirow[b]{2}{*}{ Number of fields surveyed } & \multicolumn{6}{|c|}{ Number of samples positive by DIBA ${ }^{a}$} \\
\hline & & CMV & MNSV & PRSV-W & SqMV & WMV-2 & ZYMV \\
\hline Atoka & 24 & $0 / 219$ & $12 / 219$ & $107 / 219$ & $8 / 219$ & $35 / 219$ & $28 / 219$ \\
\hline Blaine & 23 & $3 / 338$ & $0 / 338$ & $173 / 338$ & $25 / 338$ & $63 / 338$ & $67 / 338$ \\
\hline Jefferson & 7 & $0 / 64$ & $0 / 64$ & $33 / 64$ & $0 / 64$ & $23 / 64$ & $2 / 64$ \\
\hline Tulsa & 36 & $9 / 428$ & $23 / 428$ & $227 / 428$ & $7 / 428$ & $25 / 428$ & $4 / 428$ \\
\hline Total & 90 & $12 / 1049$ & $35 / 1049$ & $540 / 1049$ & $40 / 1049$ & $146 / 1049$ & $101 / 1049$ \\
\hline Infected $(\%)^{\mathrm{b}}$ & $\ldots$ & 1.1 & 3.3 & 51.4 & 3.8 & 13.9 & 9.6 \\
\hline
\end{tabular}

a Number of positive samples/total samples. DIBA = dot-immunobinding assay. Viruses: CMV = Cucumber mosaic virus, MNSV = Melon necrotic spot virus, PRSV-W = Papaya ringspot virus-watermelon strain, SqMV = Squash mosaic virus, WMV-2 = Watermelon mosaic virus-2, and ZYMV = Zucchini yellow mosaic virus.

$\mathrm{b}$ Percentage of samples positive in all counties.

\section{Discussion}

This study showed the natural distribution and occurrence of cucurbit and watermelon viruses in commercial fields in four counties of Oklahoma. The previous study by Damicone et al. (6) reported the incidence of five viruses (CMV, PRSV-W, WMV-2, SqMV, and ZYMV in pumpkin from field trials at two locations where WMV-2 was the more prevalent virus when compared with PRSV-W. Similarly, the incidence of SqMV was higher than ZYMV. Our results indicate that, out of six viruses detected from watermelon and other cucurbit crops grown in the commercial grower's fields in Oklahoma (Table 1), the percent infection of PRSV-W (48 to 53\%) was higher than WMV-2 (5 to 35\%) and the incidence of ZYMV was also more than SqMV. PRSV-W, WMV-2, and ZYMV were the most widespread viruses infecting watermelon and other cucurbit crops in all four counties of Oklahoma. All three viruses belong to the genus Potyvirus and are transmitted in a nonpersistent manner by aphids, which are difficult to control. These three viruses, along with $\mathrm{CMV}$, are a major impediment to the production of cucurbits in the United States and other parts of the world $(16,27)$.

Among the three widely distributed viruses in Oklahoma, PRSV$\mathrm{W}$ had the highest incidence in all four counties, infecting various cucurbit crops, and was the most frequent virus detected. PRSV-W was also detected in four different weed species during the study and almost $50 \%$ of the positive weed species were infected with PRSV-W. Palmer's Amaranth in the Amarantheceae family, ground cherry, and nightshade in the Solanaceae family are common throughout the fields in Oklahoma. None of these weed species have been reported previously to be the hosts of PRSV-W, either naturally or experimentally (30). This suggests that PRSV-W may survive in various weed species not belonging to the family Cucurbitaceae that could serve as reservoirs early in the season for aphid vectors of PRSV-W. This would allow PRSV-W to be spread more rapidly and to occur with high incidence (Table 4).

However, findings of studies conducted in other states on the incidence of PRSV-W are not the same as the results in this study. For example, WMV-2 was reported to be the most widespread virus compared with CMV, PRSV-W, and ZYMV in melon-growing areas of California (10), cucurbit crops in New Jersey (7), summer squash in South Carolina (34), squash and watermelon in Florida (31), and pumpkin and squash in Illinois (14). Similarly, Lecoq and Pitrat (17) reported high incidence of ZYMV compared with PRSV-W and WMV-2. This variation in the incidence of these viruses in different locations could be due to the initial sources of inocula, hosts, locations, and transmission vectors early in the season. We did not observe any aphid vectors at the time of this study.

It was interesting that the incidence of CMV was very low compared with the remaining viruses detected. The reason for this limited distribution is unknown. CMV has a wide host range, infecting more than 1,200 plant species in 100 families (8), and occurs worldwide, including Oklahoma. It is possible that the CMV inoculum sources, whether infected seed or aphid vectors, were not available to spread CMV during the 2008 to 2010 growing seasons in Oklahoma, even though CMV was identified in five pepper samples which may have come from infected pepper seed (2).

The incidence of SqMV was low compared with other viruses identified. This low incidence may be due to the absence of inoculum sources in other hosts because SqMV has limited host range to species only in the Cucurbitaceae family.

MNSV was detected only in samples from 2008 and was never detected in 2009 and 2010. Unfortunately, we did not store infected samples in the first year of collection to reconfirm the presence of MNSV in those samples. The absence of samples positive for MNSV in 2009 and 2010 may be because the crops were grown in different fields. MNSV is transmitted in soil by zoospores of the chytrid fungus (Olpidium radicale) and has been reported to be seed transmitted in melon (13).

Mixed infection of the three Potyvirus spp. PRSV-W, WMV-2 and ZYMV is not a new finding. Similar mixed infections were observed in summer squash in California (34).

Results with random PCR could be useful to obtain virus-like sequences in an unknown sample. Our results confirmed the identity of one known TRSV from cocklebur. TRSV has been reported to infect cucurbit crops (27) in other states. This is the first report that TRSV infected cocklebur in Oklahoma. In addition, identification of virus-like sequences from horse nettle and possibly from Palmer's Amaranth gives some indication that weed species may harbor other viruses.

Information about the virus infection of weeds with Potyvirus spp., particularly PRSV-W, will be helpful in future control strategies for cucurbit growers in Oklahoma by allowing the growers to eradicate sources of infection within or around the field that could then reduce the level of virus inoculum. Further studies are planned to screen seed sources, identify respective aphid vectors of the known viruses (particularly the three Potyvirus spp.), and characterize possible new viruses perpetuating in weed species in Oklahoma.

\section{Acknowledgments}

This work was supported partly by Oklahoma NSF EPSCOR award number EPS-0447262 and Office of Research and Sponsored Program, The University of Tulsa, grant number 2021211474. We thank P. Hill for careful review of this article; L. Brandenberger (Oklahoma State University [OSU], Stillwater), S. Gray (Tulsa County OSU Extension), and B. Bruton (United States Department of Agriculture-Agricultural Research Service, Lane, OK) for their consistent support during the collection of samples; and J. Shrefler (OSU, Stillwater) for the identification of weed species.

\section{Literature Cited}

1. Adlerz, W. C., Purcifull, D. E., Simone, G. W., and Hiebert, E. 1983. Zucchini yellow mosaic virus: a pathogen of squash and other cucurbits in Florida. Proc. Fla. State. Hortic. Soc. 96:72-74.

2. Ali, A., and Kobayahsi, M. 2010. Seed transmission of Cucumber mosaic virus in pepper. J. Virol. Methods 163:234-237.

3. Ali, A., and Randles, J. W. 1997. Early season survey for pea viruses in Pakistan and the detection of two new pathotypes of Pea seed-borne mosaic potyvirus. Plant Dis. 81:343-347.

4. Altschul, S. F., Madden, T. L., Schaffer, A. A., Zhange, J., Zhange, Z., Miller, W., and Lipman, D. J. 1997. Gapped BLAST and PSI-BLAST: A new generation of protein database search programs. Nucleic Acid Res. 25:33893402 .

5. Chala, V. H., Harrison, C. W., and Halliwell, R, S. 1987. Identification of two strains of watermelon mosaic virus 2 affecting cucurbits in Texas. Plant 
Dis. 71:750-752

6. Damicone, J. P., Edelson, J. V., Sherwood, J. L., Myers, L. D., and Motes, J. E. 2007. Effects of border crops and intercrops on control of cucurbit virus diseases. Plant Dis. 91:509-516.

7. Davis, R. E., and Mizuki, M. K. 1987. Detection of cucurbit viruses in New Jersey. Plant Dis. 71:40-44.

8. Edwardson, J. R., and Christie, R. G. 1991. Cucumoviruses. Pages 293-319 in: CRC Handbook of Viruses Infecting Legumes. CRC Press, Boca Raton, FL.

9. Francki, R. I. B., Mossop, D. W., and Hatta, T. 1979. Cucumber mosaic virus. AAB Description of Plant Viruses, No. 213.

10. Grafton-Cardwell, E., Perring, E., Smith, T. M., Valencia, R. F., and Farrar, C. A. 1996. Occurrence of mosaic viruses in melons in the Central Valley of California. Plant Dis. 80:1092-1097.

11. Halliwell, R. S., Johnson, J., and Cotner, S. 1979. Watermelon mosaic virus disease of squash, watermelon, and pumpkin. Texas Agric. Exp. Stn. Misc. Publ. No. 1435.

12. Harveson, R. M., Halliwell, R. S., and Johnson, J. 1990. The identification and distribution of cucurbit viruses in Texas. Texas Agric. Exp. Stn. Misc. Publ. No. 1698.

13. Hibi, T., and Furuki, I. 1985. Melon necrotic spot virus. AAB Description of Plant Viruses, No. 302.

14. Jossey, S., and Babadoost, M. 2008. Occurrence and distribution of pumpkin and squash viruses in Illinois. Plant Dis. 92:61-68.

15. Lecoq, H. 2003. Cucurbits. Pages 665-687 in: Virus and Virus-like Diseases of Major Crops in Developing Countries. G. Loebenstein and G. Thottapilly, eds. Kluwer Academic Publishers, Dordrecht, The Netherlands.

16. Lecoq, H., Dafalla, G., Desbiez, C., Wipf-Scheibel, C., Delecolle, B., Lanina, T., Ullah, Z., and Grumet, R. 2001. Biological and molecular characterization of Moroccan watermelon mosaic virus and a potyvirus isolate from Eastern Sudan. Plant Dis. 85:547-552.

17. Lecoq, H., and Pitrat, M. 1985. Specificity of the helper-component-mediated aphid transmission of three potyviruses infecting muskmelon. Phytopathology 75:890-893.

18. Lecoq, H., Wilser, G., and Pitrat, M. 1998. Cucurbit viruses: the classics and the emerging. Pages 126-142 in: Evaluation and Enhancement of Cucurbits Germplasm. J. D. McCreight, ed. American Society of Horticultural Sciences, Alexandria VA.

19. Lisa, V., Boccardo, G., D'Agostino, G., Dellavalle, G., and d'Aquilio, M. 1981. Characterization of a potyvirus that causes zucchini yellow mosaic. Phytopathology 71:667-672.

20. Lisa, V., and Lecoq H. 1984. Zucchini yellow mosaic. AAB Description of Plant Viruses, No. 282.

21. Lovisolo, O. 1980. Virus and viroid disease of cucurbits. Acta Hortic.
$88: 33-82$

22. McLean, D. M., and Meyer, H. M. 1961. A survey of cucurbit viruses in the lower Rio Grande Valley of Texas: preliminary report. Plant Dis. Rep. 45:137-139.

23. Melcher, U., Muthukumar, V., Wiley, G. B., Min, B. E., Palmer, M. W., Verchot-Lubicz, J., Ali, A., Nelson, R. S., Roa, B. A., Thapa, V., and Pierce, M. L. 2008. Evidence for novel viruses by analysis of nucleic acids in viruslike particle fractions from Ambrosia psilostachya. J. Virol. Methods 152:49-55.

24. Milne, R. G. 1987. The economic impact of filamentous plant viruses. Pages 331-407 in: The Plant Viruses, vol. 4. Plenum Press, New York

25. Nameth, S. T., Dodds, J. A., Paulus, A. O., and Laemmlen, F. F. 1986 Cucurbit viruses of California: an ever changing problem. Plant Dis. 70:8-11.

26. NASS, National Agricultural Statistics Service-United States Department of Agriculture. 2007. www.nass.usda.gov

27. Provvidenti, R. 1996. Diseases caused by virus. Pages 37-45 in: Compendium of Cucurbit Diseases. T. A. Zitter, ed. American Phytopathological Society, St. Paul, MN.

28. Provvidenti, R., Gonsalves, D., and Humaydan, H. S. 1984. Occurrence of Zucchini yellow mosaic virus in cucurbit for Connecticut, New York, Florida and California. Plant Dis. 68:443-446.

29. Purcifull, D. E., Gonsalves, D., Edwardson, J., and Heibert, E. 1984. Papaya ringspot virus. AAB Description of Plant Viruses, No. 292.

30. Purcifull, D. E., Heibert, E., and Edwardson, J. 1984. Watermelon mosaic virus 2. AAB Description of Plant Viruses, No. 293.

31. Purcifull, D. E., Heibert, E., Petersen, M. A., Simone, G. W., Kucharek, T. A., Gooch, M. D., Crawford, W. E., Beckman, K. A., and De Sa, P. B. 1998. Partial characterization of a distinct potyvirus isolated from watermelon in Florida. Plant Dis. 82:1386-1390.

32. Roossinck, M. J., Saha, P., Wiley, G. B., Quan, J., White, J. D., Lai, H., Chavarria, F., Shen, G., and Roe, B. A. 2010. Ecogenomics: using massively parallel pyrosequencing to understand virus ecology. Mol. Ecol. 19:81-88

33. Sambrook, J., Fritsch, E. F., and Maniatis, T. 1989. Molecular Cloning: A Laboratory Manual. Cold Spring Harbor Laboratory Press, Cold Spring Harbor, NY.

34. Sammons, B., Barnett, O. W., Davis, R. F., and Mizuki, M. K. 1989. A survey of viruses infecting yellow summer squash in South Carolina. Plant Dis. 73:401-404.

35. Ullman, D. E., Cho, J. J., and German, T. L. 1991. Occurrence and distribution of cucurbit viruses in the Hawaiian Islands. Plant Dis. 75:367-370.

36. Webb, S. E., and Linda, S. B. 1993. Effect of oil and insecticide on epidemics of potyviruses in watermelon in Florida. Plant Dis. 77:869-874. 